\title{
The outcomes of psychotherapy in mixed features personality disorders:
}

\section{a systematic review}

\author{
Sandra Silva ${ }^{1}$, Helena Donato 2 , Nuno Madeira ${ }^{1}$ \\ 1 Psychiatry Department, Coimbra Hospital University Centre, Coimbra, Portugal. \\ 2 Documentation Department, Coimbra Hospital University Centre, Coimbra, Portugal.
}

Received: 9/29/2018 - Accepted: 10/10/2018

DOl: 10.1590/0101-60830000000180

\begin{abstract}
Mixed features personality disorders (PDs) are highly prevalent and associated with significant burden of disease. Despite that, it has been an overlooked diagnostic category with respect to clinical research. This study aims to review empirical evidence about psychotherapy delivery available for these patients. We present a systematic review of clinical trials investigating the outcomes of psychotherapeutic interventions in adults with a primary diagnosis of mixed features PDs. Data were obtained from Medline/PubMed, Embase and PsycINFO. Seven studies met inclusion criteria; in one of them the whole sample was of this diagnostic group; two studies analysed psychotherapeutic intervention outcomes in this population, among other types of PDs, yet drawing specific conclusions on mixed features PDs patients; remaining studies addressed patient samples with different PDs types, mixed features included, where specific findings in this group of patients were not described - nonetheless, they included representative numbers of subjects with the diagnosis of interest. Available studies suggest that mixed features personality pathology per se does not seem to be an impediment to benefit from psychotherapeutic treatment, and improvement in different areas of life is possible for patients undergoing psychotherapy. The extant literature is marked by multiple challenges and inconsistencies across studies.
\end{abstract}

Silva S et al. / Arch Clin Psychiatry. 2018;45(6):161-6

Keywords: Personality disorder, psychological treatment, psychotherapy.

\section{Introduction}

Psychotherapy is the treatment of choice for personality disorders (PDs). This can be concluded from clinical guidelines, meta-analyses, and systematic or critical literature reviews ${ }^{1}$. Other treatments, such as pharmacological interventions, have received less empirical support 1,2 .

According to the DSM-IV-TR, the category of Personality Disorder Not Otherwise Specified (PDNOS) can be used for "disorders of personality functioning that do not meet criteria for any specific personality disorder (...), the presence of features of more than one specific personality disorder that do not meet the full criteria for any one personality disorder (mixed personality), but that together cause clinically significant distress or impairment in one or more important areas of functioning" 3 . Recently, with the DSM-5, this category does not appear under this heading. The category of Other Specified Personality Disorder applies to similar presentations but is used in situations in which the clinician chooses to communicate the specific reason that the presentation does not meet the criteria for any specific personality disorder (...) by recording Other Specified Personality Disorder followed by the specific reason (e.g., "mixed personality features") 4 .

Some of the structured diagnostic interviews have included directions for assigning a PDNOS diagnosis mixed type. In different approaches, it should be applied when the subject is one criterion below the diagnostic threshold for 2 or more PDs; it requires the presence of at least 10 criteria from the specific PDs; or it only requires that the subject meets traits from more than one specific $\mathrm{PD}$, in addition to the general PD criteria $^{5}$. On the other hand, Verheul et al. reported that a cut-off of 5 criteria yielded an additional group of PDNOS patients with a similar level of functional impairment as groups defined according to cut-offs of 10 or 15 PD criteria ${ }^{5,6}$. The assessment methods tend to produce different PDNOS prevalence rates $^{7}$.

Numerous studies suggest that PDNOS is one of the most prevalent mental disorders in clinical practice 8 . A meta-analysis on the prevalence and use of PDNOS diagnoses showed that 3\%-6\% of the general population and $8 \%-13 \%$ of clinical samples met the diagnostic criteria for a PDNOS diagnosis. The relative prevalence, defined as the prevalence of PDNOS divided by the overall axis II percentage without PDNOS, was estimated at $21 \%-49 \% \%^{7}$. As is the case for patients with specific PD, the burden of disease of patients with PDNOS is high, and, in terms of quality of life, patients report a quality-of-life score on the EuroQol (EQ-5D) comparable to patients with haemodialysis, rheumatic disease, lung cancer, Parkinson's disease or diabetes type II. The diagnosis is associated with high costs for society ${ }^{8}$.

In a general population study, Johnson et al. found that adolescents and young adults in the general population diagnosed with PDNOS may be as likely as those with Cluster A, B, or C PDs to have axis I psychopathology and to have behavioural, educational, or interpersonal problems that are not attributable to co-occurring psychiatric disorders9. In contrast, the multicenter study of Verheul et al. found that PDNOS took an intermediate position between cluster $\mathrm{A}, \mathrm{B}$, or $\mathrm{C} \mathrm{PDs}$ and no $\mathrm{PD}$, regarding severity of personality pathology, symptoms, and functional impairment ${ }^{6}$. Another clinical study by Karterud et al. also found that PDNOS was associated with less severe psychopathology and better treatment response compared to patients with specific PDs ${ }^{10}$. Moreover, a few case reports of patients with a PDNOS diagnosis have been published ${ }^{11-13}$.

Mixed features PDs have been an overlooked diagnostic category with respect to clinical research. Treatment studies typically focus on formal PDs and do not report results for these groups separately even when they are included in trials. According to our knowledge, there are very few treatment studies on mixed features PD patient groups, despite their high prevalence and high burden of disease, reasons why we took an interest in the subject.

Psychotherapeutic treatments can be delivered in various formats, settings, modalities, and dosages. This study aims to review the level of empirical evidence for different formats and settings that are available for psychotherapy delivery in mixed features personality disorders. 


\section{Methods}

This review was performed according to the PRISMA guidelines ${ }^{14}$, thus providing a comprehensive framework which objectively assesses indicators of quality and risk of biases of included studies.

All original studies investigating the outcomes of psychotherapeutic interventions in adults (age between 18 and 65 years) with a primary diagnosis of mixed features personality disorders were eligible for this systematic review. Further criteria adopted were: (1) publication date in the last decade, between January 2007 and June 2017, (2) empirical study, and (3) written in English, Portuguese or Spanish language. Additionally, studies were excluded from review if they were: (1) single-case report, (2) review articles, (3) repeated study population, or (4) too small sample size (less than one-third of the total sample studied in cases where specific findings in mixed features PD are not described).

As this review focused on efficacy and effectiveness of interventions, naturalistic/non-controlled studies were included.

Studies were identified by searching relevant papers via PubMed/ Medline (http://www.ncbi.nlm.nih.gov/pubmed), PsycINFO and Embase using the following keywords in combination: "personality disorders"; "psychological treatment", and "psychotherapy". Finally, reference lists of retrieved studies were hand searched to identify any additional relevant studies.

After performing the initial literature searches, each study title and abstract was screened for eligibility by the first author. Full texts of all potentially relevant studies were subsequently retrieved and further examined for eligibility. The PRISMA flow diagram (Figure 1)

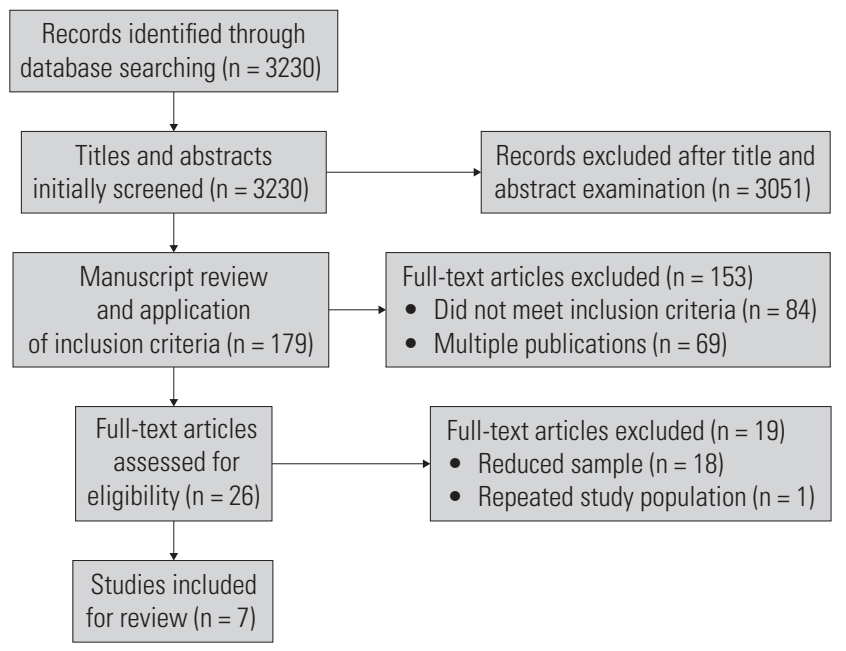

Figure 1. PRISMA flow diagram of the study selection process. provides more detailed information regarding the selection process of studies. Information from the included studies was then analysed and recorded in an electronic spreadsheet designed by the first author. Different types of data were extracted from each study including: (a) country in which the data were collected, (b) participants' characteristics (including diagnosis, age and gender), (c) number of subjects, (d) type of intervention (including modality, setting and duration of treatment) (e) type of outcome measure, (f) main results, and (g) study limitations.

ROBINS-I and Cochrane Collaboration's tool for assessing risk of bias were adopted to evaluate the risk of bias in individual studies ${ }^{15,16}$. The following risk of biases were analysed: (1) bias due to confounding, (2) bias in selection of participants, (3) bias in classification of interventions, (4) bias due to deviations from intended interventions, (5) bias due to missing data, (6) bias in measurement of outcomes, and (7) bias in selection of reported results. The assessments were completed by the first and third authors independently.

\section{Results}

Seven articles investigating the outcomes of psychotherapeutic interventions in adults with primary diagnosis of mixed features PDs were included in this review. One of them specifically focused on this diagnostic group, which corresponds to the study's whole sample ${ }^{8}$. Two other studies analysed the effectiveness of psychotherapeutic interventions in mixed features PDs, among other PDs types, yet drawing concrete conclusions for this specific patient subgroup ${ }^{17,18}$. The remaining four studies ${ }^{19-22}$ were concerned with intervention outcomes in samples of patients with different PDs types, mixed features personality disorders included, where specific findings about this patient group were not described. Despite that, they included a representative number of subjects with the diagnosis of interest (at least one-third of the total sample studied) and, henceforth, its results were of interest to this review.

Four studies were from The Netherlands, two were from Norway, and one from Poland. Reviewed studies included 399 participants with a primary diagnosis of mixed features PD. Considering that six of the studies include varied samples and not only the mentioned diagnosis, known data related to gender distribution and average age are relative to whole samples and not only to this subgroup.

A summary of results is presented in Table 1 and risk of bias in individual studies based on ROBINS-I and Cochrane Collaboration's tool for assessing risk of bias is presented in Table 2 . As shown in this table, deviations from intended interventions was the most frequent bias, with six of seven studies assessed having moderate risk for this type of bias. No bias due to confounding and in selection of reported result were found, although the risk of bias was not always clear.

Table 1. Effectiveness of psychotherapeutic interventions in adults with primary diagnosis of mixed features personality disorders

\begin{tabular}{|c|c|c|c|c|c|}
\hline Study & $\begin{array}{l}\text { Country; } \\
\text { Study design }\end{array}$ & Subjects & Type of intervention & $\begin{array}{l}\text { Type of outcome measure; Main } \\
\text { findings }\end{array}$ & Study limitations \\
\hline $\begin{array}{l}\text { Horn et al., } \\
2015^{8}\end{array}$ & $\begin{array}{l}\text { The Netherlands; } \\
\text { Multicenter quasi- } \\
\text { experimental }\end{array}$ & $\begin{array}{l}\text { PDNOS N }=205 \\
(100 \% \text { of the sample): } \\
-\mathrm{PD} \text { mixed only } \\
(65 \%) \text {; } \\
- \text { Appendix PD only } \\
(17 \%) \text {; } \\
-\mathrm{PD} \text { mixed and } \\
\text { appendix PD (18\%) } \\
\text { Mean age } 35.1(\mathrm{SD} \\
=10.3) \text { years } 72 \% \\
\text { female. }\end{array}$ & $\begin{array}{l}\text { Short-term ( } \leq 6 \text { months) and } \\
\text { long-term (> } 6 \text { months) outpatient, } \\
\text { day hospital and inpatient } \\
\text { psychotherapy } \\
\text { Psychodynamic }(27 \%) \text {, cognitive- } \\
\text { behavioural }(21 \% \text { ) or integrative } \\
\text { orientation }(52 \%) 60 \text { months } \\
\text { follow-up. }\end{array}$ & $\begin{array}{l}\text { Symptom severity; Psychosocial } \\
\text { functioning; Quality of life } \\
\text { Patients in all treatment modalities } \\
\text { showed positive outcomes } \\
\text { at short-term and long-term } \\
\text { follow-ups, especially in terms of } \\
\text { improvements of symptom severity } \\
\text { and social role functioning. } \\
\text { Short-term outpatient } \\
\text { psychotherapy and short-term } \\
\text { inpatient psychotherapy seem to } \\
\text { be superior at 12-month follow- } \\
\text { up. At 60-month after baseline, } \\
\text { effectiveness remained but } \\
\text { observed differences between } \\
\text { modalities mostly diminished. }\end{array}$ & $\begin{array}{l}\text { Not a randomized controlled trial. } \\
\text { Difference of loss to follow-up. } \\
\text { Did not take into acount other } \\
\text { treatment attributes - potential } \\
\text { impact of theoretical orientation } \\
\text { and medication use, or patient } \\
\text { attributes - axis I comorbidity. } \\
\text { Effectiveness is determined by } \\
\text { self-report, without information } \\
\text { if whether patients still meet } \\
\text { criteria for a PD diagnosis after } \\
5 \text { years. } \\
\text { Sites overlapped only partially in } \\
\text { terms of the (equal) availability } \\
\text { of the six modalities. }\end{array}$ \\
\hline
\end{tabular}




\begin{tabular}{|c|c|c|c|c|c|}
\hline Study & $\begin{array}{l}\text { Country; } \\
\text { Study design }\end{array}$ & Subjects & Type of intervention & $\begin{array}{l}\text { Type of outcome measure; Main } \\
\text { findings }\end{array}$ & Study limitations \\
\hline $\begin{array}{l}\text { Horn et al., } \\
2015^{17}\end{array}$ & $\begin{array}{l}\text { The Netherlands; } \\
\text { Matched-control study }\end{array}$ & $\begin{array}{l}\text { PDNOS N }=61 \\
\text { (42\% of the STIP-TA } \\
\text { patients and } 49 \% \text { of } \\
\text { the OP patients) } \\
\text { Mean age } 39.4 \text { (SD } \\
\text { 9.8) years in STIP-TA } \\
\text { patients, and } 39.3 \text { (SD } \\
10.2 \text { ) in OP patients } \\
70 \% \text { female. }\end{array}$ & $\begin{array}{l}\text { Short-term (3-month) inpatient } \\
\text { Psychotherapy based on } \\
\text { transactional analysis (STIP- } \\
\text { TA) and other psychotherapies } \\
\text { (OP) varying widely in terms of } \\
\text { setting, duration, and theoretical } \\
\text { orientation } 36 \text { months follow-up. }\end{array}$ & $\begin{array}{l}\text { General psychiatric } \\
\text { symptomatology; Psychosocial } \\
\text { functioning; Quality of life } \\
\text { At } 36 \text { months, 68\% of STIP-TA } \\
\text { patients were symptomatically } \\
\text { recovered compared to } 48 \% \text { of OP } \\
\text { patients. STIP-TA outperformed } \\
\text { OP in terms of improvements } \\
\text { in general psychiatric } \\
\text { symptomatology and quality of life. } \\
\text { Superiority of STIP-TA was most } \\
\text { pronounced at 12-month follow- } \\
\text { up, but remained intact over the } \\
\text { course of the 3-year follow-up. } \\
\text { A very promising and effective } \\
\text { treatment option in mainly } \\
\text { PDNOS patients. }\end{array}$ & $\begin{array}{l}\text { Not a randomized controlled } \\
\text { trial. } \\
\text { Only self-report instruments } \\
\text { used as outcome measures. } \\
\text { Information about the treatment } \\
\text { fidelity and adherence was not } \\
\text { collected. } \\
\text { The interpretation of the results } \\
\text { is limited by the variation of } \\
\text { treatment modalities in the OP } \\
\text { condition. }\end{array}$ \\
\hline $\begin{array}{l}\text { Kvarstein et } \\
\text { al., } 201718\end{array}$ & $\begin{array}{l}\text { Norway; } \\
\text { Naturalistic study }\end{array}$ & $\begin{array}{l}\text { PDNOS N }=18 \\
(17.4 \% \text { of the sample) } \\
\text { Mean age } 38.5 \text { (SD } \\
\text { 10) years } 60 \% \text { female. }\end{array}$ & $\begin{array}{l}\text { Outpatient } \\
\text { Psychodynamic groups, mean } \\
\text { treatment duration } 1.5 \text { (SD 0.9) } \\
\text { years 3-year follow-up. }\end{array}$ & $\begin{array}{l}\text { Symptom distress; Interpersonal } \\
\text { problems; Occupational } \\
\text { functioning; Psychiatric health } \\
\text { service use. } \\
\text { PDNOS benefits across all } \\
\text { outcomes. The most favourable } \\
\text { outcomes were found for patients } \\
\text { with PDNOS. } \\
\text { PDNOS patients may be well } \\
\text { managed within outpatient group } \\
\text { therapy. }\end{array}$ & $\begin{array}{l}\text { Naturalistic designs limits } \\
\text { inferences on outcome as an } \\
\text { effect of the treatment. } \\
\text { Dual roles of clinicians and } \\
\text { researches may also limit validity } \\
\text { of patient reported ratings. } \\
\text { Diagnostic procedures held a } \\
\text { high standard, but reliability was } \\
\text { not investigated. }\end{array}$ \\
\hline $\begin{array}{l}\text { Chakhssi et } \\
\text { al., 201519 }\end{array}$ & $\begin{array}{l}\text { The Netherlands; } \\
\text { Nonrandomized } \\
\text { exploratory study }\end{array}$ & $\begin{array}{l}\text { PDNOS N = } 38 \text { (48.3\% } \\
\text { of the ACT patients } \\
\text { and } 42.9 \% \text { of the CBT- } \\
\text { TAU patients) } \\
\text { Mean age } 32.88 \text { (SD } \\
10.13 \text { ) years in ACT } \\
\text { patients, and } 33.26 \\
\text { (SD 9.63) in CBT- } \\
\text { TAU patients } 82.7 \% \\
\text { female. }\end{array}$ & $\begin{array}{l}\text { Specialized day hospital setting } \\
\text { for patients with personality } \\
\text { disorders that did not respond } \\
\text { to previous treatments 26-week } \\
\text { group-based acceptance and } \\
\text { commitment therapy (ACT). } \\
\text { Same duration group-based } \\
\text { treatment-as-usual based on } \\
\text { cognitive behaviour therapy } \\
\text { (CBT-TAU) } \\
\text { Both supplemented by arts } \\
\text { therapy, including creative and } \\
\text { drama therapy, and rehabilitation } \\
\text { counselling. }\end{array}$ & $\begin{array}{l}\text { Change in personality pathology; } \\
\text { General psychological functioning; } \\
\text { Experimental avoidance; Coping } \\
\text { skills; Positive outcomes; Quality } \\
\text { of life } \\
\text { Group-based interventions for } \\
\text { treatment-resistant patients } \\
\text { with personality disorders led } \\
\text { to significant improvements in } \\
\text { personality pathology, general } \\
\text { psychological functioning, } \\
\text { coping skills and quality of life, } \\
\text { regardless of whether participants } \\
\text { received ACT or CBT-TAU. } \\
\text { In group analysis, no main effect } \\
\text { of therapy condition was observed } \\
\text { on the outcome measures. } \\
\text { Assessment of change on an } \\
\text { individual level showed that a } \\
\text { significantly higher percentage } \\
\text { of participants receiving ACT } \\
\text { improved on personality pathology. }\end{array}$ & $\begin{array}{l}\text { Patients were not randomized. } \\
\text { Treatment fidelity was not } \\
\text { assessed. } \\
\text { The unequal sample size across } \\
\text { groups may have affect the } \\
\text { results. } \\
\text { The patients were not only } \\
\text { provided with ACT or CBT-TAU } \\
\text { but also with other treatments, } \\
\text { and the effect of these } \\
\text { treatments on the outcomes } \\
\text { remains unknown. } \\
\text { Medication use during the study } \\
\text { was not measured. } \\
\text { No independent data was } \\
\text { available on the type and quality } \\
\text { of previous outpatient treatment } \\
\text { interventions. } \\
\text { Do not report results for the } \\
\text { PDNOS group separately. }\end{array}$ \\
\hline $\begin{array}{l}\text { Schaap et } \\
\text { al., 201620 }\end{array}$ & $\begin{array}{l}\text { The Netherlands; } \\
\text { Naturalistic } \\
\text { prospective study }\end{array}$ & $\begin{array}{l}\text { PDNOS N }=24 \\
\text { (42.9\% of treatment } \\
\text { completers and } 26.1 \% \\
\text { of dropouts) } \\
\text { Mean age } 26.94 \text { (SD } \\
6.45) \text { years } 72.3 \% \\
\text { female. }\end{array}$ & $\begin{array}{l}12 \text { months group schema therapy } \\
\text { (ST) inpatient for patients with } \\
\text { PDs who did not respond to } \\
\text { previous psychotherapy } \\
\text { Specific ST techniques, } \\
\text { psychodrama, art, movement and } \\
\text { music therapies, social services, } \\
\text { pharmacotherapy, } \\
\text { education about medication } 6 \\
\text { months follow-up. }\end{array}$ & $\begin{array}{l}\text { Maladaptive schemas; Schema } \\
\text { modes; Maladaptive coping } \\
\text { styles; Mental well-being; } \\
\text { Psychological distress after } \\
\text { treatment } \\
\text { Over participants improved } \\
\text { significantly on all outcome } \\
\text { measures from pretreatment } \\
\text { to posttreatment, and these } \\
\text { improvements were maintained at } \\
\text { follow-up. } \\
\text { Experienced parenting styles } \\
\text { was the one area that showed no } \\
\text { improvement. } \\
\text { These findings are comparable } \\
\text { with treatment results for patients } \\
\text { without such a nonresponsive } \\
\text { treatment history. }\end{array}$ & $\begin{array}{l}\text { Lack of a control-group. } \\
\text { Treatment fidelity was not } \\
\text { assessed. } \\
\text { The patients were not only } \\
\text { provided with ST, but also with } \\
\text { additional therapies. } \\
\text { Diagnosis were based on the } \\
\text { clinical judgement and not by } \\
\text { structured interviews. } \\
\text { The relationship between } \\
\text { the YSQ (Young schema } \\
\text { questionnaire) and SMI (Short } \\
\text { schema mode inventory) was } \\
\text { large. } \\
\text { Do not report results for the } \\
\text { PDNOS group separately. }\end{array}$ \\
\hline
\end{tabular}




\begin{tabular}{|c|c|c|c|c|c|}
\hline Study & $\begin{array}{l}\text { Country; } \\
\text { Study design }\end{array}$ & Subjects & Type of intervention & $\begin{array}{l}\text { Type of outcome measure; Main } \\
\text { findings }\end{array}$ & Study limitations \\
\hline $\begin{array}{l}\text { Cyranka et } \\
\text { al., 201621 }\end{array}$ & $\begin{array}{l}\text { Poland; } \\
\text { Naturalistic study }\end{array}$ & $\begin{array}{l}\text { Mixed features PDs } \\
\mathrm{N}=34 \text { : } \\
\text { - Other PDs ( } 24 \% \text { of } \\
\text { the sample); } \\
\text { - Mixed and other } \\
\text { PDs ( } 15 \% \text { of the } \\
\text { sample); } \\
\text { - PDs unspecified (2\% } \\
\text { of the sample) } \\
\text { Mean age } 31.5 \text { (SD } \\
\text { 6.9) years } 74 \% \text { female }\end{array}$ & $\begin{array}{l}\text { 10-14 weeks intensive short-term } \\
\text { group psychotherapy in a day } \\
\text { ward with elements of individual } \\
\text { therapy } \\
\text { Integrated the elements of } \\
\text { psychodynamic, cognitive and } \\
\text { behavioural theories }\end{array}$ & $\begin{array}{l}\text { Personality functioning using } \\
\text { MMPI-2 clinical scales. } \\
\text { Having undergone the } \\
\text { psychotherapy treatment, the } \\
\text { majority of the examined were } \\
\text { observed to demonstrate positive } \\
\text { changes in personality functioning } \\
\text { which were classified as severe } \\
\text { or moderate pathology. }\end{array}$ & $\begin{array}{l}\text { Lack of a control-group. } \\
\text { Not carrying out a follow-up } \\
\text { study. } \\
\text { Not extending the analysis with } \\
\text { other questionnaire scales. } \\
\text { Do not report results for the } \\
\text { mixed features PDs group } \\
\text { separately. }\end{array}$ \\
\hline $\begin{array}{l}\text { Hoglend et } \\
\text { al., } 201122\end{array}$ & $\begin{array}{l}\text { Norway; } \\
\text { Randomized } \\
\text { controlled clinical trial }\end{array}$ & $\begin{array}{l}\text { PDNOS N }=19(35 \% \\
\text { of transference } \\
\text { group and } 49 \% \text { of } \\
\text { comparison group) } \\
\text { Mean age } 34.9 \\
\text { (SD } 8.7) \text { years in } \\
\text { transference patients, } \\
\text { and } 32.7 \text { (SD 9.5) in } \\
\text { comparison patients } \\
63 \% \text { female. }\end{array}$ & $\begin{array}{l}1 \text { year of dynamic psychotherapy } \\
\text { with low to moderate use of } \\
\text { transference interpretations } \\
\text { (transference group). } \\
\text { Dynamic psychotherapy without } \\
\text { this component (comparison } \\
\text { group). } \\
\text { Both with other treatments } \\
\text { components such as clarifications, } \\
\text { confrontations and extra- } \\
\text { transference interpretations. }\end{array}$ & $\begin{array}{l}\text { Remission from personality } \\
\text { disorder; Improvement in } \\
\text { interpersonal functioning; Use of } \\
\text { mental health resources in the } \\
\text { 3-year period after treatment } \\
\text { termination. } \\
\text { After therapy with transference } \\
\text { interpretation, PD-patients } \\
\text { improved significantly more } \\
\text { in core psychopathology and } \\
\text { interpersonal functioning, the } \\
\text { drop-out rate was reduced to } \\
\text { zero, and use of health services } \\
\text { was reduced to 50\%, compared to } \\
\text { therapy without this ingredient. } \\
\text { Three years after treatment } \\
\text { termination, 73\% no longer met } \\
\text { diagnostic criteria for any PD in } \\
\text { the transference group, compared } \\
\text { to } 44 \% \text { in the comparison group. }\end{array}$ & $\begin{array}{l}\text { Only clinician-rated outcome } \\
\text { measures were used. } \\
\text { No longer meeting full criteria } \\
\text { for any PD may be seen as a } \\
\text { problematic measure of recovery, } \\
\text { since it also may include patients } \\
\text { who just drop one criterion } \\
\text { below the cut-off scores for a } \\
\text { definite diagnosis. } \\
\text { Primary outcome (recovery from } \\
\text { PD) was based on non-blind } \\
\text { ratings. } \\
\text { Do not report results for the } \\
\text { PDNOS group separately. } \\
\end{array}$ \\
\hline
\end{tabular}

Table 2. Assessment of risk of bias in individual studies

\begin{tabular}{|l|c|c|c|c|c|c|c|}
\hline Study & $\begin{array}{c}\text { Bias due to } \\
\text { Confounding }\end{array}$ & $\begin{array}{c}\text { Bias in Selection } \\
\text { of Participants }\end{array}$ & $\begin{array}{c}\text { Bias in } \\
\text { Classification of } \\
\text { Interventions }\end{array}$ & $\begin{array}{c}\text { Bias due to } \\
\text { Deviations } \\
\text { from Intended } \\
\text { Interventions }\end{array}$ & $\begin{array}{c}\text { Bias due to } \\
\text { Missing Data }\end{array}$ & $\begin{array}{c}\text { Bias in } \\
\text { Measurement of } \\
\text { Outcomes }\end{array}$ & $\begin{array}{c}\text { Bias in Selection } \\
\text { of the Reported } \\
\text { Result }\end{array}$ \\
\hline Horn et al.8 & Low & Moderate & Moderate & Moderate & Moderate & Low & Low \\
\hline Horn et al.17 & Low & Moderate & Moderate & Moderate & Moderate & Low & Low \\
\hline Kvarstein et al.18 & Low & Low & Low & Moderate & Low & Moderate & Low \\
\hline Chakhssi et al.19 & Low & Moderate & Low & Moderate & Low & Low \\
\hline Schaap et al..20 & Low & Low & Low & Moderate & Low & Moderate & Low \\
\hline Cyranka et al.21 & Low & Moderate & Low & Moderate & Moderate & Moderate & Low \\
\hline Hoglend $e t$ al.22 & Low & Moderate & Low & Low & Low & Low & Low \\
\hline
\end{tabular}

\section{Discussion}

Being psychotherapy the treatment of choice for personality disorders, and with so few treatment studies on mixed features PDs, despite their high prevalence and high burden, the authors addressed and reviewed empirical evidence for different formats, settings, modalities and dosages that are available for psychotherapy delivery in adults with this primary diagnosis. Psychotherapy treatment studies typically focus on specific PDs types, with borderline PD being more extensively studied than any other PD; results for mixed features PDs are unfrequently reported in separate, even when they are included in trials.

We chose to include: (1) studies that analysed psychotherapeutic intervention outcomes in these patients, even among samples with other types of PDs, drawing concrete conclusions for the group, and (2) studies where specific findings in this group of patients are not reported as long as they included a representative number of subjects with this diagnosis (at least one-third of the total sample studied), so the results could be somehow applicable to this subgroup. Eighteen full-text articles assessed for eligibility were excluded due to small (up to $21 \%$ participants) sample size, making its results extrapolation inadequate.

Horn et al. ${ }^{8}$ specifically focuses on PDNOS patients, a group that corresponded to the total studied sample. It was the first large-scale treatment study in patients with PDNOS, having investigated the effectiveness of different psychotherapy modalities in patients with PDNOS, i.e., short-term and long-term outpatient, day hospital and inpatient psychotherapy. The treatments offered included varied theoretical orientations, such as psychodynamic orientation $(27 \%$ of all given treatments), a cognitive-behavioural orientation (21\% of all given treatments) or an integrative orientation (combining different theoretical frameworks, $52 \%$ of all given treatments). Patients in all treatment modalities showed positive outcomes at short-term and long-term follow-ups, especially in terms of improvements of symptom severity and social role functioning. Short-term outpatient 
psychotherapy and short-term inpatient psychotherapy seem to be superior at 12-month follow-up, and at 60-month after baseline, effectiveness remained but observed differences between modalities mostly diminished.

In fact, cognitive-behavioural and psychodynamic approaches have been the object of the most extensive research in patients with PDs.

Cognitive behavioural therapy (CBT) is well suited to address the varied and often long-standing problems of patients with PDs for several reasons. From a cognitive behavioural perspective, PDs are maintained by a combination of maladaptive beliefs about self and others; contextual/environmental factors that reinforce problematic behaviour and/or undermine effective behaviour; and skill deficits that preclude adaptive responding. CBT incorporates a wide range of techniques to modify these factors, including cognitive restructuring, behaviour modification, exposure, psychoeducation, and skills training. In addition, CBT for PDs emphasizes the importance of a supportive, collaborative, and well-defined therapeutic relationship, which enhances the patient's willingness to make changes and serves as a potent source of contingency. In sum, several aspects of CBT's conceptual framework and its technical flexibility make it appropriate to address the pervasive and diffuse impairment commonly observed among patients with $\mathrm{PDs}^{23,24}$.

Psychoanalytic psychotherapy, also referred to as psychodynamic psychotherapy, is a type of therapy that incorporates concepts such as the unconscious, the use of defense mechanisms, and the role of an individual's past via their social processes such as attachment and early childhood experience. The approach provides useful tools for expanding, consolidating, and enriching one's own life and one's relationships with others. Contemporary psychodynamic therapy involves many Freudian concepts, such as the existence of the unconscious, yet it has also moved away from a purely Freudian focus on drive, ego, and conflict. Contemporary psychodynamic theory includes a rich body of theory, and now incorporates various aspects of many $20^{\text {th }}$ century psychoanalytic theories including object relations, self-psychology, interpersonal/relational theory, attachment theory, trauma theory, and intersubjective theory ${ }^{25}$.

In another study, Horn et al. ${ }^{17}$ compared 3-month short-term inpatient psychotherapy based on transactional analysis (STIP-TA) with other psychotherapies (OP) up to 36-month follow-up. At 36 months, $68 \%$ of STIP-TA patients were symptomatically recovered compared to $48 \%$ of OP patients. This therapy outperformed OP in terms of improvements in general psychiatric symptomatology and quality of life. That superiority was most pronounced at 12-month follow-up but remained intact over the course of the 3-year follow-up. The authors concluded that it could be a very promising and effective treatment option in mainly PDNOS patients, which corresponded to $42 \%$ of the STIP-TA patients and $49 \%$ of the OP patients. Kvarstein et al. ${ }^{18}$ also conclude that PDNOS patients may be well managed within outpatient group therapy, in a trial involving outpatient psychodynamic groups with mean treatment duration 1.5 years and 3-year follow-up evaluating symptom distress, interpersonal problems, occupational functioning, and psychiatric health service use. The most favourable outcomes were found exactly for patients with PDNOS.

The remaining four studies included for review ${ }^{19-22}$ do not report results for the mixed features PDs patients group separately. Both Chakhssi et al..$^{19}$ and Schaap et al. ${ }^{20}$ studied PDNOS patients, among others, that did not respond to previous treatments. The first compared day hospital group-based acceptance and commitment therapy (ACT) and group-based treatment-as-usual based on cognitive behaviour therapy (CBT-TAU), led to significant improvements in personality pathology, general psychological functioning, coping skills and quality of life in both groups. The second author and colleagues evaluated the outcomes of an impatient group schema therapy (ST) in maladaptive schemas, schema modes, maladaptive coping styles, mental well-being, and psychological distress after treatment. Overall, participants improved significantly on all outcome measures from pretreatment to posttreatment, and these improvements were maintained at 6-month follow-up. Experienced parenting styles was the one area that had no improvement.
Cyranka et al. ${ }^{21}$ evaluated intensive short-term group psychotherapy in a day ward with elements of individual therapy, integrating the elements of psychodynamic, cognitive and behavioural theories, in mixed features PDs patients, which demonstrated positive changes in personality functioning which were classified as severe or moderate pathology. Hoglend et al.22 carried out the only randomized controlled trial included in this review, comparing 1 year of dynamic psychotherapy with low to moderate use of transference interpretations and dynamic psychotherapy without this component in a sample including PDNOS patients. After therapy with transference interpretation, patients improved significantly more in core psychopathology and interpersonal functioning, the drop-out rate was reduced to zero, and use of health services was reduced to $50 \%$, compared to therapy without this ingredient. Three years after treatment termination, $73 \%$ no longer met diagnostic criteria for any PD in the transference group, compared to $44 \%$ in the comparison group.

Researchers have highlighted the diversity of treatments as an obstacle to identifying efficacious treatments ${ }^{26}$. In addition, some authors emphasize that instead of conducting further comparisons of different treatments, research should be concentrated on the active ingredients of treatments ${ }^{17,27}$.

Various independent psychotherapies demonstrated efficacy for these patients. However, several factors limit our ability to draw strong conclusions from available research. Overall, the limited number of studies included, with only one randomized controlled trial, is insubstantial. Although certainly lacking the rigor of RCTs, uncontrolled studies can provide clinically important information about mechanisms of change and moderators of treatment outcome. In addition to their use for driving theory and hypotheses for testing in future RCTs, uncontrolled studies can be useful for uncovering essential qualities of effective interventions and the effectiveness of psychotherapy as it is delivered in the field. Furthermore, cooccurring of other disorders, particularly within Axis I conditions, the possibility that maturational processes or life events may be responsible for part of the changes measured, and the use of medications along with the psychotherapy, further hampers existing research. An additional concern is substantial heterogeneity among studies included in the review. Besides, differences with respect to therapy format, the length, patient samples, gender distribution, and length of follow-up periods are very variable.

Subgroup analysis directed at "what works for whom" could give more valuable information for clinical practice about which treatments work best for which category of patients instead for which category of diagnosis. This is even more important in this patient group since various definitions of PDNOS are used in clinical practice and across studies, limiting the comparability and generalizability of study findings ${ }^{5,7,8,28}$.

Despite previously mentioned limitations, findings from recent studies make an important contribution to our understanding of the role of psychotherapy in mixed features PDs.

\section{Conclusions}

Despite the toll of mixed features PDs on healthcare systems, there are vast gaps in the treatment literature on these disorders, a frequently overlooked mental health problem, for which there are no established psychosocial treatments.

Overall, there are some psychotherapeutic approaches with different modalities and durations offered to these individuals, and the research findings we reviewed suggest that there is hope for significant and meaningful changes after psychotherapy in individuals with PDNOS.

The most important conclusion is that mixed features personality pathology per se does not seem to be an impediment to benefit from psychotherapy, and improvement in different areas of life is possible for the patients who undergo psychotherapeutic treatment. It would be important to make psychotherapy more accessible for this patient group in order to reach health gains for this vulnerable group of psychiatric patients. 
Although promising in many ways, the extant literature is marked by multiple challenges and inconsistencies across studies. Further research on the effectiveness of psychotherapy for mixed features PD patients is undoubtedly needed.

\section{References}

1. Verheul R, Herbrink M. The efficacy of various modalities of psychotherapy for personality disorders: a systematic review of the evidence and clinical recommendations. Int Rev Psychiatry 2007;19(1):25-38.

2. Binks CA, Fenton M, McCarthy L, Lee T, Adams CE, Duggan C. Psychological therapies for people with borderline personality disorder. Cochrane Database Syst Rev. 2006;25(1):CD005653.

3. American Psychiatric Association. Diagnostic and statistical manual of mental disorders. 4th ed. Text revision. Washington, DC: APA; 2000.

4. American Psychiatric Association. Diagnostic and statistical manual of mental disorders. 5th ed. Washington, DC: APA; 2013.

5. Wilberg T, Hummelen B, Pedersen G, Karterud S. A study of patients with personality disorder not otherwise specified. Comp Psychiatry. 2008;49(5):460-8.

6. Verheul R, Bartak A, Widiger T. Prevalence and construct validity of personality disorder not otherwise specified (PDNOS). J Pers Disord. 2007;21(4):359-70.

7. Verheul R, Widiger TA. A meta-analysis of the prevalence and usage of the personality disorder not otherwise specified (PDNOS) diagnosis. J Pers Disord. 2004;18(4):309-19.

8. Horn EK, Bartak A, Meerman AMMA, Rossum BV, Ziegler UM, Thunnissen $\mathrm{M}$, et al. Effectiveness of psychotherapy in personality disorders not otherwise specified: a comparison of different treatment modalities. Clin Psychol Psychother. 2015;22(5):426-42.

9. Johnson JG, First MB, Cohen P, Skodol AE, Kasen S, Brook JS. Adverse outcomes associated with personality disorder not otherwise specified in a community sample. Am J Psychiatry. 2005;162(10):1926-32.

10. Karterud S, Pedersen G, Bjordal E, Brabrand J, Friis S, Haaseth O, et al. Day treatment of patients with personality disorders: experiences from a Norwegian treatment research network. J Pers Disord. 2003;17(3):243-62.

11. Newman CF. A case illustration of resistance from a cognitive perspective. J Clin Psychology. 2002;58(2):145-9.

12. Savoja V, Sani G, Kotzalidis GD, De Rossi P, Stefani S, Pancheri L, et al. Bipolar disorder presenting as stalking - A case report. Psychiatr Danub. 2011;23(1):69-72.

13. Warren R. A cognitive-behavioural perspective on personality disorders with over-regulation of emotions and poor self-reflectivity: the case of a man with avoidant and not-otherwise specified personality disorder, social phobia and dysthymia treated with metacognitive interpersonal therapy. Personal Ment Health. 2012;6(2):170-3.

14. Moher D, Liberati A, Tetzlaff J, Altman DG; PRISMA group. Preferred reporting items for systematic reviews and meta-analyses: the PRISMA statement. Open Med. 2009;3(3):123-30.
15. Stern JAC, Hernán MA, Reeves BC, Savovic J, Berkman ND, Viswanathan $\mathrm{M}$, et al. ROBINS-I: a tool for assessing risk of bias in non-randomised studies of interventions. BMJ. 2016;355:14919.

16. Higgins JPT, Green S (Eds.). Cochrane handbook for systematic reviews of interventions version 5.1.0 [updated March 2011]. The Cochrane Collaboration, 2011. Available from: www.handbook.cochrane.org. Accessed in: November 2017.

17. Horn EK, Verheul R, Thunnissen M, Delimon J, Soons M, Meerman AMMA, et al. Effectiveness of short-term inpatient psychotherapy based on transactional analysis with patients with personality disorders: a matched control study using propensity score. J Pers Disord. 2015;29(5):663-83.

18. Kvarstein EH, Nordviste O, Dragland L, Wilberg T. Outpatient psychodynamic group psychotherapy - outcomes related to personality disorder severity, age and gender. Personal Ment Health. 2017;11(1):37-50.

19. Chakhssi F, Janssen W, Pol SM, Dreumel MV, Westerhof GJ. Acceptance and commitment therapy group-treatment for non-responsive patients with personality disorders: an exploratory study. Personal Ment Health. 2015:9(4):345-56.

20. Schaap GM, Chakhssi F, Westerhof GJ. Inpatient schema therapy for nonresponsive patients with personality pathology: Changes in symptomatic distress, schemas, schema modes, coping styles, experienced parenting styles, and mental well-being. Psychotherapy (Chic). 2016;53(4):402-412.

21. Cyranka K, Rutkowski K, Mielimaka M, Sobanski JA, Smiatek-Mazgaj $\mathrm{B}$, Klasa $\mathrm{K}$, et al. Changes in personality functioning as a result of group psychotherapy with elements of individual psychotherapy in persons with neurotic and personality disorders - MMPI-2. Psychiatr Pol. 2016;50(1):105-26.

22. Hoglend P, Dahl HS, Hersoug AG, Lorentzen S, Perry JC. Long-term effects of transference interpretation in dynamic psychotherapy of personality disorders. Eur Psychiatry. 2011;26(7):419-24.

23. Matusiewicz AK, Hopwood CJ, Banducci AN, Lejuez CW. The effectiveness of cognitive behavioral therapy for personality disorders. Psychiatr Clin North Am. 2010;33(3):657-85.

24. Beck AT, Freeman A, Davis DD. Cognitive therapy of personality disorders. New York: Guilford Press; 2004.

25. Rorie K. Psychodynamic Psychotherapy for Personality Disorders: A Systematic Review. Master of Social Work Clinical Research Papers 2016; Paper 662.

26. Bateman AW, Fonagy P. Effectiveness of psychotherapeutic treatment of personality disorder. Br J Psychiatry. 2000;177:138-43.

27. Clarkin JF. An integrated approach to psychotherapy techniques for patients with personality disorder. J Pers Disord. 2012;26(1):43-62.

28. Coccaro EF, Nayyer H, McCloskey MS. Personality disorder-not otherwise specified evidence of validity and consideration for DSM-5. Compr Psychiatry. 2012;53(7):907-14 